\title{
DISTRIBUTION OF ABO AND Rh BLOOD GROUPS AMONG TRIBAL POPULATION OF SYLHET, BANGLADESH
}

\author{
BEGUM D ${ }^{1}$, AMIN MR ${ }^{2}$, KHATUN F$^{3}$, AHMED SS ${ }^{4}$, SINHA SK ${ }^{5}$, RAHMAN MA ${ }^{6}$

\begin{abstract}
Context: Distribution of blood groups varies among ethnic groups throughout the world. Blood groups of tribals should be determined as they are ethnically different from the main population of Bangladesh.
\end{abstract}

Materials and Methods: To observe the distribution pattern of $A B O$ and $R h$ blood groups and to compare the groups among Manipuris (1434) and Khasias (204), this descriptive crosssectional study was conducted in the Department of Physiology, Dhaka Medical College, Dhaka, from July 2006 to June 2007. Manipuris were divided in Bishnupriya (658), Meitei (460) and Meitei-Pangan (316) according to their ethnic origin. Data were collected from Manipuri (12) and Khasia (2) localities selected by systematic random sampling. ABO and Rh blood groups of participants were determined by the antigen antibody agglutination test of slide method. Data from groups were compared by chi-square test with 95\% confidence limit.

Results: There are significant variations in the distribution of $A B O(p<0.001)$ and $R h(p<0.001)$ blood groups among all study groups. Blood group A was more frequent among Meiteis (40\%) and Meitei-Pangans (42.41\%) whereas blood group $O$ was more frequent in Bishnupriyas (47.72\%) and Khasias (35.29\%). In all tribal communities, AB blood group was least frequent. Rh positive participants (97.43\%) were more than Rh negative (2.57\%). In Khasias, no Rh negative group was found. Rh negativity was more in Bishnupriyas (4.9\%) which was significantly higher than Meiteis (0.87\%) and Meitei-Pangans. (1.94\%) $\left(X^{2}=16.7 ; p<0.001\right)$.

Conclusion: Distribution of $A B O$ blood groups varies among the Manipuris and Khasias. Significant variation is also found in three groups of Manipuris and the distribution corresponds with the pattern of their ancestors.

Key words: $A B O$ blood group, Rh blood group, tribal population, Sylhet.

J Dhaka Med Coll. 2011; 20(1) : 44-50.

\section{Introduction:}

On the basis of ethnicity, world population is divided in many groups. The extent to which these groups resemble or differ from each other in terms of purely genetic traits is of great interest. Blood groups are the simple and useful tool can be use for the purpose. The relative frequency of $\mathrm{O}, \mathrm{A}, \mathrm{B}$ and $\mathrm{AB}$ blood group in Western Europe are $46 \%, 42 \%, 9 \%$ and $3 \%$ respectively. ${ }^{1}$ In the United States, the frequency of $\mathrm{O}, \mathrm{A}, \mathrm{B}$ and $\mathrm{AB}$ blood group is $45 \%, 41 \%, 10 \%$ and $4 \% .{ }^{2}$ Some of the Eastern European show higher percentage of blood group B. Pure American Indians belongs almost exclusively to group O. ${ }^{3}$ The frequency of Group B is highest in Central Asia. ${ }^{4}$ Rh D-negativity is most common in Caucasians (15\%), less common in Blacks $(8 \%)$, and rare in Asians (1\%). ${ }^{2}$

1. Dr. Dilruba Begum, Lecturer, Department of Physiology, Dhaka Medical College, Dhaka.

2. Prof. Md. Ruhul Amin, Professor and Head, Department of Physiology, Sylhet MAG Osmani Medical College, Sylhet.

3. Prof. Firoza Khatun, Professor and Head, Department of Physiology, National Institute of Cardiovascular Disease (NICVD), Dhaka.

4. Dr. Syed Shafi Ahmed, Associate Professor, Department of Paediatrics, Bangladesh Institute of Child Health (BICH), Dhaka.

5. Dr. Sharadindu Kanti Sinha, Associate Professor, Department of Pharmacology, Jalalabad Ragib-Rabeya Medical College, Sylhet.

6. Dr. Md. Abedur Rahman, Lecturer, Department of Physiology, Dinajpur Medical College, Dinajpur.

Correspondence :Dr. Dilruba Begum, Lecturer, Department of Physiology, Dhaka Medical College, Dhaka-1000. 
Among 57 tribal groups of Bangladesh, Manipuris and Khasias are living in Sylhet division. ${ }^{5}$ Manipuris were migrated from Manipur, the state of India and living in all four districts of Sylhet division. The majority of them are living in different villages of Kamalgonj Thana under Moulvibazar district. According to ethnic origin three divisions of Manipuris are Bishnupriyas, Meiteis and Meitei-Pangans. Bishnupriyas are mainly of Indo-Aryan, Meitei are of Mongoloid and MeiteiPangans are admixture of both Indo-Aryan and Mongoloid ethnic groups. Meitei-Pangans are also known as Muslim Manipuris. They are distinct from Meiteis and Bishnupriyas in terms of religion and culture. However, they speak in Meiteilon, the mother-tongue of the Meiteis. ${ }^{6,7}$ Meiteis are distinct from Bishnupriyas by language and appearance. However, both the group follows almost same culture, custom and religion. ${ }^{8}$ The Khasias are mongoloid in origin migrated to Bangladesh from Meghalaya of India. ${ }^{9}$ They live in peak of hills known as 'punji. There are about 70 punjis scattered in the border region Moulvibazar, Sunamgonj and Sylhet district. ${ }^{10}$

The first documented genetic study including blood groups in Manipuris was conducted by Singh et al. ${ }^{11}$ carried on Meiteis and Brahmins caste in Manipur, India. Study of 16 red cell antigens showed that the Meiteis and Brahmins are very close to each other with respect to most of the loci except Gm, EsD and $\mathrm{Hb}$, where significant statistical differences were found. ${ }^{11}$

The first study addressing ABO blood groups in Bangladeshi Manipuri's was carried out by Islam et al. ${ }^{12}$ Among 700 Manipuris, blood group $A$ and $O$ was found to $42 \%$ and $41.57 \%$ respectively and $\mathrm{Rh}$ negative was $5.71 \% .{ }^{12}$ The results of the study were different from the study conducted in central part of Bangladesh ${ }^{13}$, where blood group B was predominant. In Southeast zone, the predominant blood group was $\mathrm{O}$ followed by B. ${ }^{14}$ In Eastern part of Bangladesh, O group was predominant and Western part; distribution of $\mathrm{O}$ and $\mathrm{B}$ is almost same. ${ }^{15}$
The landmark study of Haque et al. ${ }^{16}$ on Manipuris, Khasias, Santals, Garos and tribes of Chittagong Hill Tracts (CHTs) showed a remarkable high frequency of group B was of CHTs (40.11\%) and Santal (38.83\%). Both group O $(41.75 \%)$ and group A (42\%) were common types in Manipuris while only group $\mathrm{O}$ was common type in Khasias (47.37\%). Rarest blood group in all tribes was $\mathrm{AB}$ however it was higher $(13.78 \%)$ then Bangladeshi population. ${ }^{13}$ The highest frequency of Rh-D negative individual was $5.71 \%$ in Manipuris. However, the number of Rh-D negative person was nil in Khasias, Garos and Santal tribes. ${ }^{16}$

In previous studies, Manipuris were studied as a single tribal community though they are divided in three other subgroups. ${ }^{12,16}$ Therefore, this study was designed to observe the distribution of $\mathrm{ABO}$ and $\mathrm{Rh}$ blood groups in three subgroups of Manipuris. In addition, ABO and $\mathrm{Rh}$ blood groups of Khasias were studied to revalidate the absence of $\mathrm{Rh}(\mathrm{D})$ antigen among them.

\section{Materials and Methods:}

This descriptive cross-sectional study was conducted in the Department of Physiology, Dhaka Medical College, Dhaka, from July 2006 to June 2007 on Manipuris and Khasias of Sylhet division. A total 1434 Manipuris were divided in three groups according to ethnic origin. Bishnupriyas consists of 658 samples; Meiteis consists of 460 samples; MeiteiPangans consists of 316 samples. Khasias consists of 204 samples. Therefore, the total number of samples were $(1434+204)=1638$. $\mathrm{ABO}$ and $\mathrm{Rh}(\mathrm{D})$ blood grouping of all participants was done at different community centers (Mandop) of the Manipuri localities and Minster's (Headman's) house in Khasia localities using antigen antibody agglutination test of slide method.

For each Manipuri community, data were collected from three localities selected by systematic random sampling. Therefore, the total number of Manipuri localities included in the study was $(3 \times 3)=9$. The Bishnupriya localities are Tilakpur, Bhanubil and Gharamara villages of Kamalgonj thana. The 
Meiteis localities are Mangalpur, Chitlia villages of Kamalgonj thana and Shibgonj of Sylhet town. Meitei-Pangan localities are Phultali, Jamirakona and Ranirbazar villages of Kamalgonj thana. Data of Khasias were collected from two Khasia punjis - Dhanchara and Julakhachara punji, situated near the Sreemangal town under Moulvibazar district.

Statistical analyses were done by SPSS version 12.0 for windows. The result was calculated as frequency of each blood group expressed as percentage. Chi-square statistical test was done to compare the results among groups at $95 \%$ confidence interval. Informed written consent was taken from the participants and legal guardians in case of minors.

This study was approved by the Ethical Review Committee (ERC) of Dhaka Medical College, Dhaka.

\section{Results:}

Total 1638 tribal people from Bishnupriya (658), Meitei (460), Meitei-Pangan (316) and Khasia (204) communities were included in the study. Females $(62.15 \%)$ are more than males (37. $85 \%)$. Male female ratio was $1: 1.6$. The mean age of Bishnupriyas was $28.55 \pm 21.37$, which was slightly higher than Meiteis (26.21 \pm 20.82$)$, Meitei-Pangans (22.39 \pm 16.75$)$ and Khasias (23.41 \pm 17.52$)$ (Table-I).
Among all participants, blood group A was the most frequent $(650 ; 39.68 \%)$ and $\mathrm{AB}$ was the least frequent $(118 ; 7.2 \%)$. The frequency of group $\mathrm{O}(626,38.21)$ was next to the A group. The frequency of blood group B was (244; $14.90 \%)$. The differences in distribution of $\mathrm{ABO}$ blood groups among all four tribal groups were highly significant statistically $\left(\mathrm{X}^{2}=135.5\right.$; $\mathrm{p}<0.001$ ) (Table-II).

Blood group A was more frequent among Meiteis (40\%) and Meitei-Pangans (42.41\%) group whereas blood group $\mathrm{O}$ was more frequent in Bishnupriyas $(47.72 \%)$ and Khasias (35.29\%). However, the distribution of blood group A and B was equal in Khasias (Table-III).

Of 1638 participants, 1596 (97.43\%) were processed $\mathrm{Rh} \mathrm{D}$ antigen in their red cells. The differences of distribution of Rh blood group in all four communities were highly significant statistically $\left(\mathrm{X}^{2}=25.13 ; \mathrm{p}<0.001\right)$. In Khasias, all were found to be Rh positive (Table-IV).

Among the Manipuris, 3.01\% population was $\mathrm{Rh}$ negative. The distribution of $\mathrm{Rh}$ negative population was more in Bishnupriyas (4.86\%) than Meitei $(0.87 \%)$ and Meitei-Pangans (1.94\%). The differences in distribution of $\mathrm{Rh}$ blood groups in all three communities were highly significant statistically $\left(X^{2}=16.7\right.$; $\mathrm{p}<0.001)$ (Table-V).

Table- I

Age distribution of the participants

\begin{tabular}{lccccc}
\hline Groups & $\begin{array}{c}\text { Total } \\
\text { number }\end{array}$ & $\begin{array}{c}\text { Minimum } \\
\text { (Age in years) }\end{array}$ & $\begin{array}{c}\text { Maximum } \\
\text { (Age in years) }\end{array}$ & $\begin{array}{c}\text { Mean } \\
\text { (Age in years) }\end{array}$ & SD \\
\hline Bishnupriya & 658 & 0.50 & 90.00 & 28.55 & 21.37 \\
Meitei & 460 & 0.20 & 90.00 & 26.21 & 20.82 \\
Meitei-Pangan & 316 & 0.50 & 75.00 & 22.39 & 16.75 \\
Khasia & 204 & 0.50 & 65.00 & 23.41 & 17.52 \\
\hline
\end{tabular}

Table-II

Distribution of $A B O$ blood group in all participants

\begin{tabular}{|c|c|c|c|c|c|c|c|}
\hline \multirow[t]{2}{*}{ Blood Group } & \multicolumn{4}{|c|}{ Tribal groups } & \multirow[t]{2}{*}{ Total (\%) } & \multirow[t]{2}{*}{$\mathrm{X}^{2}$} & \multirow[t]{2}{*}{$\mathrm{p}$ value } \\
\hline & Bishnupriya & Meitei & Pangan & Khasia & & & \\
\hline A & 274 & 184 & 134 & 58 & 650 (39.68\%) & 135.5 & $<0.001$ \\
\hline B & 48 & 102 & 36 & 58 & 244 (14.90\%) & & \\
\hline $\mathrm{AB}$ & 22 & 52 & 28 & 16 & 118 (7.2\%). & & \\
\hline $\mathrm{O}$ & 314 & 122 & 118 & 72 & $626(38.21 \%)$ & & \\
\hline Total & 658 & 460 & 316 & 204 & 1638 & & \\
\hline
\end{tabular}


Table-III

Percent distribution of $A B O$ blood groups in all participants

\begin{tabular}{lccccc}
\hline Group & \multicolumn{5}{c}{ ABO Blood group in percentage } \\
& $\mathrm{A}$ & $\mathrm{B}$ & $\mathrm{AB}$ & $\mathrm{O}$ & Total \\
\hline Bishnupriya & $41.64 \%$ & $7.29 \%$ & $3.34 \%$ & $47.72 \%$ & $100 \%$ \\
Meitei & $40 \%$ & $22.17 \%$ & $11.3 \%$ & $26.52 \%$ & $100 \%$ \\
Meitei-Pangan & $42.41 \%$ & 11.39 & $8.86 \%$ & $37.34 \%$ & $100 \%$ \\
Khasia & $28.43 \%$ & $28.43 \%$ & $7.84 \%$ & $35.29 \%$ & $100 \%$ \\
\hline
\end{tabular}

Table-IV

Distribution of Rh blood group in all participants

\begin{tabular}{|c|c|c|c|c|c|c|c|}
\hline \multirow[t]{2}{*}{$\mathrm{Rh}$ group } & \multicolumn{4}{|c|}{ Group } & \multirow[t]{2}{*}{ Total } & \multirow[t]{2}{*}{$\mathrm{X}^{2}$} & \multirow[t]{2}{*}{$\mathrm{p}$ value } \\
\hline & Bishnupriya & Meitei & Pangan & Khasia & & & \\
\hline $\mathrm{Rh}$ negative & 32 & 4 & 6 & 0 & 42 & 25.13 & $<0.001$ \\
\hline Rh positive & 626 & 456 & 310 & 204 & 1596 & & \\
\hline
\end{tabular}

Table-V

Distribution of Rh blood group in three Manipuri communities

\begin{tabular}{lccccc}
\hline Groups & \multicolumn{2}{c}{ Rh group $\mathrm{n}(\%)$} & Total & $\mathrm{X}^{2}$ & $\mathrm{p}$ value \\
\cline { 2 - 3 } & Rh negative & Rh positive & & & \\
\hline Bishnupriya & $32(4.86 \%)$ & $626(95.14 \%)$ & 658 & 16.70 & $<0.001$ \\
Meitei & $4(0.87 \%)$ & $456(99.13 \%)$ & 460 & & \\
Meitei-Pangan & $6(1.89 \%)$ & $310(98.105)$ & 316 & & \\
\hline Total & $42(3.01 \%)$ & $1392(96.99 \%)$ & 1434 & & \\
\hline
\end{tabular}

\section{Discussion:}

This study offered the opportunity to compare blood groups data among different groups of different or closely related communities. The collected data on blood group system can be used for transfusion of blood and blood products, organ transplantation, development of legal medicine and anthropological study of a group or society. ${ }^{17,18,19}$ This study revealed that there are significant variations in the distribution of $\mathrm{ABO}$ and $\mathrm{Rh}$ blood groups among all tribal groups. Distribution of $\mathrm{ABO}$ and $\mathrm{Rh}$ blood groups were also significantly varied among all three communities of Manipuris.

Blood groups were determined with simple and classic slide method which has been used in determination of other population groups. ${ }^{14,20,21,22,23}$ The simplicity of the method has provided the screening of blood groups in large number of samples in short period of time. Other methods of blood grouping are test tube and microplate methods, though are superior over slide method but not suitable in rural settings. ${ }^{24}$

Blood group A and O were the frequent blood groups among the studied tribal groups and group $\mathrm{AB}$ was the least frequent. In earlier studies conducted by Islam et al. ${ }^{12}$ and Haque et al. ${ }^{16}$ also found similar distribution pattern of ABO blood groups in Manipuris. Among other tribal groups of CHTs and Santal, a remarkable high frequency of blood group $B$ was observed. ${ }^{12}$ However, in central region of Bangladesh, blood group B was more predominant ${ }^{13}$, though blood group $\mathrm{O}$ was found to be more frequent in South East, Western part of Bangladesh. ${ }^{14,15}$ 
In Manipuris, frequency of blood group A is the highest among Meitei and Meitei-Pangans whereas group $\mathrm{O}$ is more predominant in Bishnupriyas. In Bishnupriyas, the distribution of O, A, B and AB were $47.72 \%, 41.64 \%, 7.29 \%$ and $3.34 \%$ respectively. This type of distribution is usually seen in different population groups of Aryan origin as seen in the Western Europeans where relative frequency of O, A, B and $\mathrm{AB}$ group is $46 \%, 42 \% 9 \%$ and $3 \% .{ }^{3}$ Similar pattern of distribution was also found in the whole Manipuri community ${ }^{12}$ and in the Gurung tribe of Napal. ${ }^{20}$ The similarity may be due to the common Aryan origin ${ }^{5,8,9}$ and highest number of bishnupriyas in the study of Islam et al. ${ }^{12}$ as they did not specify the subgroups of manipuris in their study. This study revealed that the distribution pattern $\mathrm{ABO}$ blood groups in Meiteis and Meitei-Pangans are also different from the distribution pattern of Bishnupriyas. Dissimilarity is also found among Bangladeshi population ${ }^{13,14,15}$ and other tribals of Bangladesh. ${ }^{16}$ Different ethnic and racial origins may be the cause behind it.

In Meitei group, the distribution pattern of $\mathrm{A}$, $\mathrm{B}, \mathrm{O}, \mathrm{AB}$ blood groups is $40 \%, 22.17 \%, 11.3 \%$ and $26.52 \%$ respectively. Almost similar pattern of distribution was seen in Jirels, a small tribe of Nepal, descendent of Kirats (Mongoloid tribes). ${ }^{23}$ The distribution pattern is also similar to the Chhetri tribes of Nepal. ${ }^{20}$

The distribution pattern of $\mathrm{ABO}$ groups among Meiteis was dissimilar with Bangladeshi ${ }^{13,14,15}$ and whole Manipuri population. ${ }^{12}$ The distribution was also different from the distribution pattern other tribal populations such as Khasias, Santals and tribes of CHTs. ${ }^{16}$ However, similarities were found in between Meitei-Pangans with Meiteis though percentage of blood group B in MeiteiPangan is lower than that of the Meiteis. The similarity may be due to the origin of MeiteiPangan from the Meiteis. ${ }^{6,7}$ Asian Mongoloid has higher frequency of A group and relatively low B is observed in the population of Korea, Japan, several Asiatic population of Russia and North East part of India. ${ }^{25}$ The distribution pattern of Meiteis showed this pattern of distribution.
The distribution $\mathrm{A}, \mathrm{B}, \mathrm{AB}$ and $\mathrm{O}$ blood groups in Meitei-Pangnas are $42.4 \%, 11.39 \%, 8.86 \%$ and $37.34 \%$ respectively. The distribution pattern is almost similar to pattern of Meiteis which connote them as a descendent of Meiteis. ${ }^{6,7}$ However, the frequency of blood group B is somewhat different from Meiteis people which may be due to the admixture of diverse Bengal community. Muslim Manipuris are the descendants from the Bengalese of Surma Valley who married Meiteis women. 6,7

The distribution pattern of Meitei-Pangans is dissimilar with the Bishnupriyas and study on Manipuris by Islam et al. ${ }^{12}$ The different distribution pattern from Bishnupriyas may be due to separate ethnic origin. The different distribution pattern from Islam et al. ${ }^{12}$ may be due to less recruitment of Meitei-Pangan in their study. The data are different from some ethnic communities of Pakistan where blood group $\mathrm{O}$ was found as the most predominant group in all ethnic communities. ${ }^{21}$ The data are also different from the studies done on Bangladeshi 13, 14, 15 and tribal people of Bangladesh. ${ }^{16}$

The distribution $\mathrm{A}, \mathrm{B}, \mathrm{AB}$ and $\mathrm{O}$ blood groups in Khasias are $28.43 \%, 28.43 \%, 7.84 \%$ and $35.29 \%$ respectively. Similar pattern of distribution was found in the study done by Haque et al. ${ }^{16}$ and different ethnic groups of Nepal. ${ }^{20}$ The similarity of results with Nepalese population signifies the closer geographic and ethnic origin. A remarkable high frequency of B group was found in the tribes of CHTs and Santals ${ }^{16,26}$ which was different from the current study on Khasias. Distribution of blood group in Lodha tribe of Midnapore ${ }^{27}$ and tribals of Bankura districts ${ }^{28}$ showed different distribution pattern of blood groups than Khasias. The distribution pattern is also dissimilar in contrast to all Manipuri groups of present study. Separate ethnic as well as separate culture and geographical distribution may be responsible for this variation.

Of 1638 participants, 1596 (97.43\%) were Rh D positive and $42(2.57 \%)$ were $\mathrm{Rh}$ negative. The $\mathrm{Rh}$ negative frequency was more in Bishnupriya community 32 (4.9\%) than other two communities of Manipuris. However, in 
Khasia community all were found to be $\mathrm{Rh}$ positive. Rh negative phenotype is about $15 \%$ in Caucasians, $8 \%$ in black and nil or $1 \%$ in Asians. ${ }^{4}$ In addition to Khasias, in several other tribal groups, Rh antigen was not found. Nepalese ethnic groups such as Sherpa, Limbu, Gurung, Taru, Magar don't processed Rh antigen in red cells. ${ }^{20}$ In previous study on Khasia people of Bangladesh, Rh negative blood was not found; the result was consistent with the present series. ${ }^{16} \mathrm{Rh}$ negative blood group was also absent in the Santal tribe. ${ }^{26}$ Therefore, it can assume that $\mathrm{Rh}$ antigen mediated Hemolytic Disease of Newborn HDN is absent in exclusively $\mathrm{Rh}$ positive tribal groups.

Higher frequency of Rh negative blood in Bishnupriya community revealed in this study corresponds with the results of Islam et al and Haque et al. ${ }^{12,16}$ The result was significantly higher than other two groups of Manipuri community. Rh negative blood group was also frequent in Arains (8.3\%), Awans (10.4\%), Rajputs (8.5\%), Misc Punjabi (8.8\%), Balochs $(7.8 \%)$, Sindhis (8.7\%), Kashmiris (10.9\%) and Pathans $(7.7 \%)$ ethnic groups of Pakistan. ${ }^{21}$ Similarity of results may be due common Aryan origin of the ethnic groups. In Caucasians, 15\% peoples are $\mathrm{Rh}$ negative ${ }^{4}$. However, lower frequency of distribution seen among the ethnic groups may be due to other racial admixture. The low Rh negativity in Meiteis and Meiteis-Pangans corresponds with similar ethnic groups of Mongoloid origin such as Jirels, Newar ethnic groups of Nepal. ${ }^{20,23}$ Increased Rh negative frequency may increase the incidence of HDN in Bishnupriya community.

\section{References:}

1. Guyton AC, Hall JE. Blood groups; transfusion; Tissue and Organ transplantation. In: Textbook of medical physiology. $10^{\text {th }}$ ed. New Delhi: Prism Saunders; 2000. p. 413-7.

2. Ganong WF. Blood types. In: Review of medical physiology. $21^{\text {st }}$ ed. New York: McGraw-Hill; 2003. p. $539-42$.

3. Keele CA, Neil E, Joels N. The internal environment: blood groups. In: Samson Wright's applied physiology. $13^{\text {th }}$ ed. New Delhi: Oxford University Press; 2000. p. 46-51.

4. Dean L. Blood groups and red cell antigens. Available from: http://www.ncbi.nlm.nih.gov/ books/bv.fcgi?rid=rbcantigen. [Accessed on 12 . 01.2011].

5. Singha RK. Ethinc people of Banglasesh. $1^{\text {st }}$ ed. Dhaka: Manipuri Prokashoni; 2001. p. 1- 48.

6. Ahmed F. Foundation of Manipuri Muslim history. Available from: http://www.manipuronline.com/ features $/ \mathrm{htm}$. [Accessed on 11. 01. 2011].

7. Ahmed F. Pre- $14^{\text {th }}$ century Manipur: Social evolution. Available from: http:// www.manipuronline.com / Manipuris / socialevolution/htm. [Accessed on 11. 01. 2011].

8. Singha AK. The Manipuris: their custom and culture. Available from: http:// manipuri.freehomepage.com/index.html. [Accessed on 11. 01. 2011].

9. Sattar A. Aaranya Janapade. (Research on tribal peoples of Bangladesh). $2^{\text {nd }}$ ed. Dhaka: NASAS; 1975.

10. Banglapedia. Khasia. Available from: www.banglapedia.com.bd/HT/K_0215.htm. [Accessed on 10. 01. 2011].

11. Singh KS, Mukherjee BN, Walter H, Lindenberg P, Gilbert K, Dannewitz A, et al. Genetic markers among Meiteis and Brahmins of Manipur, India. Hum Hered 1986; 36: 177-87.

12. Islam MA, Rahman M, Husain M. Studies of the $\mathrm{ABO}$ and Rhesus (D) blood groups among the tribal peoples of greater Sylhet. Medicine Today 1992; 4: $14-6$.

13. Rahman M. Incidence of important blood groups in Bangladesh. Bangladesh Med Res Counc Bull 1975; 1: 60-3.

14. Hussain M, Nandy CK, Kabir KM, Haque KMG. The distribution of $\mathrm{ABO}$ and Rhesus (D) blood group systems in greater Chittagong, Noakhali and Comilla (South East zone of Bangladesh). Medicine Today 1990; 2: 33-6.

15. Nandy CK. Frequencies of the ABO blood groups in Jessore, Bangladesh. J IPGMR 1986, 1: 40-2.

16. Haque KMG, Rahman M, Hussain M. Clinically important blood group antigens in six different tribal populations of Bangladesh. Transfusion Today 1999; 34: 6-7.

17. Storry JR. Human blood groups: inheritance and importance in transfusion medicine. J Infus Nurs 2003; 26: 367-72.

18. Nydegger UE, Riedler GF, Flegel WA. Histoblood groups other than HLA in organ transplantation. Transplant Proc 2007; 39: 64-8.

19. Jolly JG. Medicolegal significance of human blood groups. J Indian Med Assoc 2000; 98: 340-1. 
20. Pramanik T, Adhikari P. Trend of blood group distribution among the different ethnic groups of Katmandu Valley. Nepal Med Coll J 2006; 8: 2489.

21. Ali N, Anwar M, Bhatti FA, Nadeem M, Nadeem A, Ali AM. Frequency of ABO and Rh blood groups in major ethnic groups and casts of Pakistan. Pak J Med Sci 2005; 21: 26-9.

22. Anees M, Mriza MS. Distribution of ABO and Rh blood group alleles in Gujrat region of Punjab, Pakistan. Proc Pakistan Acad Sci 2005; 42: 2338.

23. Chapagain RH, Subba B, Kunwar CB, Subedi J, Blengero J, Williams S, et al. Trend of blood group distribution among the Jirels of Nepal. J Nepal Med Assoc 2005; 44: 121-3.

24. Waters AH. Red cell blood-group antigens and antibodies. In: Dacie VJ, Lewis SM. eds. Practical
Haematology. $8^{\text {th }}$ ed. London: Churchill Livingstone; 1995. p. 445-64.

25. Majumder PP, Roy J. Distribution of ABO Blood groups on the Indian subcontinent: a cluster-analytic approach. Curr Anthropol 1982; 23: 539-66.

26. Roychoudhury A, Mukherjee MJ, Talukder G, Sharma A. The blood group and haemoglobin types of the Santals. J Indian Med Assoc. 1992; 90: 240-1.

27. Datta UK, Mondal S, Mukherjee S. A study of the distribution of $\mathrm{ABO}$ and $\mathrm{Rh}$ (D) blood groups amongst Lodha tribe in Midnapore district of West Bengal. J Indian Med Assoc 1997; 95: 497-8, 506.

28. Choudhury A, Dutta UK, Bhattacharyya AK, Mukherjee S. Epidemiological studies of blood groups in the district of Bankura with special reference to tribals. J Indian Med Assoc 1994; 92: 291-2. 